\title{
РЕЦЕНЗИИ
}

DOI: $10.22363 / 2313-0660-2017-17-2-416-424$

\section{РЕЦЕНЗИЯ НА МОНОГРАФИЮ: \\ Little, D. Us versus Them: The United States, Radical Islam, and the Rise of the Green Threat. Chapel Hill: University of North Carolina Press, 2016. - 314 p. ISBN 978-1-4696-2680-2}

\author{
И.А. Соков
}

Волгоградский государственный университет, Волгоград, Россия

В 2016 г. было опубликовано исследование профессора истории Университета Кларка (США) Дугласа Литтла «Мы против них: Соединенные Штаты, радикальный ислам и подъем зеленой угрозы». Безусловно, эта монография актуальна для современных международных отношений, в которых проблема международного терроризма стала одной из важнейших тем как для изучения исследователями, так и для обсуждения широкой общественностью.

Прежде всего, следует обратить внимание читателя на название книги — «Мы против них...», а не «Они против нас...». Автор сам объясняет, почему так названо его произведение: «Я намеренно написал эту книгу с точки зрения „нас“, а не „их“, не потому что я считаю, то как мусульмане думают, не имеет никакого значения или оно маловажно, а потому, что зеленая угроза, которая достаточно много преобладает в дискурсе относительно радикального ислама в США, была создана американской политикой, поп-культурой и общественным мнением» [Little 2016: 14].

Монография состоит из введения, шести глав, примечаний, библиографии, индекса и карт.

Во введении Д. Литтл кратко излагает историю ислама, происхождение в нем различных течений, возвышение и падение исламских государств, возрождение ислама в 80-е гг. XX в. с падением коммунистических режимов и замещением для США потенциальной «красной угрозы» реальной «зеленой угрозой». Исламский радикализм достаточно быстро перерос в терроризм за период с ноября 1979 г., когда «сторонники аятоллы Хомейни заняли американское посольство в Тегеране и держали пятьдесят два американца заложниками в течение 444 дней» [Там же: 10] до событий в Нью-Йорке 9 сентября 2001 г.

По мнению автора, ошибки четырех последних правительств в определении политики национальной безопасности США в отношении «зеленой угрозы» не только не ограничили влияние радикального ислама в мире, но и способствовали «исламизации Америки» [Там же: 13]. 
B первой главе Д. Литтл анализирует роль сдерживания (containment) в политической истории и в политической культуре Соединенных Штатов, утверждая, что всегда «американцы были склонны рассматривать мир с точки зрения „мы против них“» [Там же: 15]. Сначала это была индейская «красная угроза», затем «черная угроза» американского Юга и восстаний рабов на островах Карибского бассейна, «желтая угроза» хлынувших иммигрантов на западное побережье США, «коричневая угроза» во время Второй мировой войны, «новая красная угроза» со стороны Советского Союза во время холодной войны, которая сменилась «зеленой угрозой» в новом тысячелетии.

Автор утверждает, что все возникавшие расовые или идеологические угрозы всегда представляли собой экзистенциальную опасность для Америки. С другой стороны, он указывает на то, что постепенно сдерживание переместилось с американского континента на другие континенты, а условия сдерживания потребовали проведение американских войн, начиная с Кореи и заканчивая Афганистаном и Ираком.

Во второй главе Д. Литтл анализирует первую американскую войну на Ближнем Востоке, операцию «Буря в пустыне» в январе 1991 г., которая не достигла цели создания нового порядка в регионе Персидского залива, создав «проарабский и антиизраильской мир» [Там же: 54]. В то же время автор признает, что «проблема Саддама Хуссейна» была создана самими американцами в результате сначала политики сдерживания Ирана, а затем противоположной политики «Ирангейта» (Irangate) — сдерживания Ирака [Там же: 65].

Важно отметить, что Д. Литтл на основании первоисточников сообщает читателю, что в то время была альтернатива американскому военному вмешательству на Ближнем Востоке.

19 октября 1990 г. известный советский арабист Е.М. Примаков в овальном кабинете Белого дома предложил Дж. Бушу-ст. компромиссный вариант, позволяющий иракскому лидеру сохранить «свое лицо» в арабском мире и одновременно вывести свои войска из Кувейта. Для этого было достаточно, чтобы Израиль передал палестинцам земли на западном берегу р. Иордан. «,Не загоняйте Саддама в угол“, - сказал Примаков президенту Бушу» [Там же: 75].

У американского президента на тот момент имелись проблемы, которые были сопряжены с Ираком: 3800 американских граждан работали в Ираке и Кувейте и могли стать заложниками С. Хусейна; Сенат США по вопросу войны и мира занимал неопределенную позицию; Советский Союз мог наложить вето в Совете Безопасности ООН на резолюцию, санкционирующую военные действия США на Ближнем Востоке.

Между тем, как выяснил автор монографии, «Кремлевские лица, принимающие решения, испытывали на самом деле гораздо меньше симпатии к Саддаму Хусейну, чем Примаков старался уверить Буша» [Там же: 75]. 8 ноября 1990 г. государственный секретарь США Джим Бейкер посетил М.С. Горбачева в Кремле и получил от него заверения в поддержке американского военного вмешательства (заметим, до решения самого американского сената. - И.С.). Это дало возможность, как пишет Д. Литтл, получить «преимущество в победе Буша в сенате, со- 
ставившее 52 голоса против 47, благодаря полудюжине демократов, в том числе Альберту Гору из Теннесси, которые обеспечили решающие голоса» [Там же: 76]. В дальнейшем, за 100 часов блицкрига (с 24 по 28 февраля 1991 г.) американский генерал Норман Шварцкопф-мл. (Norman Schwarzkopf Jr.) освободил Кувейт, Ирак потерял 20000 человек мертвыми и еще 60000 ранеными, американцев было убито в бою 148 человек [Там же: 77]. «Шварцкопф был готов к походу на иракскую столицу и к смене режима, но Белый дом забеспокоился, что штурм Багдада приведет к разрыву антисаддамовской коалиции и создаст вакуум власти в Персидском заливе, что будет только на пользу Ирану» [Там же: 77].

Далее, в этой же главе Д. Литтл анализирует арабо-израильский мирный процесс и влияние распада СССР на рост исламского фундаментализма.

Третья глава посвящена анализу «расширения» (enlargement) нового униполярного американского порядка в период президентства Б. Клинтона и политике «двойного сдерживания» (dual containment) США на Ближнем Востоке, которая заключалась в одновременной изоляции Ирака и Ирана, угрожавших «безопасности Израиля и доступу Америки к нефти Персидского залива» [Там же: 92]. Такую политику американские «мозговые центры» назвали проектом «Новый американский век» (Project for a New American Century).

Но «миссия расширения» (mission enlargement) не обошлась без американского военного вмешательства - «нас против них», сначала в Боснии, затем в Сомали. Позднее были проведены операции «Лиса пустыни» (Desert Fox), «Бдительный воин» (Vigilant Warrior) и планировалась, но не состоялась операция «Гадюка пустыни» (Desert Viper) в Ираке. Причем, как замечает автор, «,двойное сдерживание“ было ключевым компонентом более широкой стратегии расширения правительства Клинтона» [Там же: 108] и оно было различным в достижении целей. В отношении Ирака - это было «агрессивное сдерживание» (aggressive containment), в результате которого ожидалась смена режима путем внутреннего разрушения, подобно СССР. Что касается Ирана - это было «активное сдерживание» (active containment), не предусматривающее смену режима, а лишь «дипломатическую изоляцию и односторонние американские экономические санкции» [Там же: 108] как ответ на его противодействие усилиям США по мирному арабоизраильскому процессу.

В этой же главе Д. Литтл анализирует политический процесс мирных арабо-израильских переговоров при посредничестве США и делает вывод о том, что оно не достигло никаких результатов, потому что не решило основных вопросов конфликта: вопрос статуса восточного Иерусалима и передачи территорий на западном берегу р. Иордан палестинцам. Кроме того, хотя автор вскользь упоминает, что внешняя политика правительства Б. Клинтона не приняла «хантингтонизм» (huntingtonism), все же она проводила политику двойных стандартов, деля джихадистов на хороших и плохих.

Даже взрыв американского военного корабля «Коул», отправленного на дно в Аденской гавани, унесший жизнь 17 моряков и ранив 39 человек, не открыл военные действия против террористов. По мнению автора рецензируемого издания, «хорошо зная об опасностях военного вмешательства в третьем мире, Клинтон 
намеревался положиться на «мягкую силу» для продвижения мира и процветания, и он решил, что внешняя политика не должна отвлекать его от насущных экономических вопросов, близко связанных с внутренними вопросами» [Там же: 128].

$B$ четвертой главе Д. Литтл анализирует политику противодействия «зеленой угрозе» правительством Дж. Буша-мл. По его мнению, новый президент поделил соперников на международной арене на «страны-изгои» (rogue states), к которым он отнес Ирак, Афганистан, Северную Корею, и «врагов свободы» (enemies of liberty), к которым отнес Россию и Китай [Там же: 129]. По отношению к первым, получившим определение «ось зла» (Axis of Evil), Белый дом решил применить «доктрину превентивной войны» (doctrine of preventive war), ко вторым — «бинарную логику холодной войны» [Там же: 132].

«Мягкая сила» и общественная дипломатия правительства Б. Клинтона заменялась «дипломатией большой дубинки» (big-stick diplomacy) правительством Дж. Буша-мл. [Там же: 134]. Кроме этого, автор считает, что правительством Дж. Буша-мл. были неправильно расставлены приоритеты в организации национальной безопасности. Им была принята изначально установка, что негосударственные акторы, такие как Усама бен Ладен (UBL) и Аль-Каида представляют меньшую угрозу, чем государства-противники.

В своем исследовании Д. Литтл указывает, что в администрации президента были две группы специалистов, работающих в области безопасности: новая команда, поддерживающая точку зрения президента и оставшиеся специалисты от команды Б. Клинтона, которые считали основной угрозой США террористические группы, а не государства.

Более того, автор полагает, что ужасные события 9/11 можно было предотвратить. При подготовке передачи власти вновь избранному президенту Дж. Бушу-мл. в подготовленной справке директор ЦРУ Дж. Тенет «разместил Аль-Каиду первой в списке» указав, что вероятными целями могли бы стать «американские сооружения на ближнем Востоке, особенно, на Аравийском полуострове, в Турции и Западной Европе ... сеть бен Ладена глобальна ... и способна к нападениям в других регионах, включая США» [Там же: 142].

При первой двухчасовой встрече с Дж. Бушем-мл. в овальном кабинете Б. Клинтон сказал своему преемнику: «Я думаю, что вы найдете, что вашей самой большой угрозой будет бен Ладен и Аль-Каида. Одним из наибольших извинений за мое президентство является то, что я не заполучил его для вас, сколько бы я не пытался» [Там же: 142].

Примерно то же сказал Сэмюэл Ричард Бергер (Sandy Berger), советник по вопросам национальной безопасности Б. Клинтона, своему преемнику Кандолизе Райс: «Я хочу подчеркнуть, насколько важна эта проблема. Вы потратите больше времени за свои четыре года на борьбу с терроризмом в целом и на АльКаиду, в частности, чем на любую другую проблему» [Там же: 142].

Как видим, предупреждения были основательными.

25 января 2001 г., спустя 5 дней как К. Райс разместилась в новом офисе западного крыла Белого дома, Ричард Кларки (Richard Clarke), глава антитеррористической группы по обеспечению безопасности (Counterterrorism Security 
Group - CSG), представил ей отчет, в котором указал, что Аль-Каида - это не узкая территориальная проблема, а межнациональный вызов.

Д. Литтл считает, что сложившееся двоякое представление в решении первоначальной угрозы для США в период с января по сентябрь 2001 г., не позволило своевременно на нее реагировать. Проект президентской директивы против агрессивных действий Аль-Каиды лежал «на столе президента, ожидающий его подписи, когда самолет Боинг-767 авиакомпании «Американ Эйрлайнс» с пассажирами на борту врезался в северную башню Всемирного торгового центра в 8:46 утра 11 сентября, во вторник» [Там же: 145].

По оценке Дж. Буша-мл. день 11 сентября 2001 г. стал «днем беспрецедентного национального позора, начиная с 7 декабря 1941 г. „Перл-Харбор 21-го столетия“"» [Там же: 146].

После события 9/11 сразу же поменялись акценты. Президент на объединенной сессии конгресса 20 сентября сказал: «Наш враг - это радикальная сеть террористов и каждое правительство, которое поддерживает их» [Там же: 146], а Пентагон стал планировать операцию «Несокрушимая свобода» (Enduring Freedom) в Афганистане.

В обращении к нации 29 января 2002 г. президент Буш указывал, что операция «Несокрушимая свобода» преследует две цели: уничтожение двух фронтов терроризма Талибан и Аль-Каиду и строительство демократического режима в Афганистане под руководством Хамида Карзая.

Как считает Д. Литтл, «хотя нет доказательств того, что Ирак или Иран обладали оружием массового поражения или что эти государства намеревались предоставить такое оружие Аль-Каиде, администрация Буша настаивала на иной версии и развернула широкую антитеррористическую кампанию» [Там же: 152]. Для ее реализации Белый дом разрешил ЦРУ передавать подозреваемых террористов иностранным разведывательным службам для проведения пыток, проводить пристрастные допросы и использовать зверские методы, запрещенные Женевской конвенцией. Чиновниками Министерства обороны США была выработана доктрина упреждающей самообороны (doctrine of anticipatory self-defense), которая предусматривала использование военной силы против любой страны в случае возникающих подозрений об угрозе с ее стороны.

К 20 сентября 2002 г. СНБ подготовила доктрину национальной безопасности, главная идея которой заключалась в превентивных мерах, включая использование военной силы, для нераспространения ядерного оружия в мире. Один из разделов этого документа, названный «Предотвращение тому, чтобы наши враги угрожали нам, нашим союзникам и нашим друзьям оружием массового поражения» впоследствии стал именоваться как доктрина Буша.

По мнению автора монографии, использование принципа превентивности по отношению к Ираку было обусловлено еще и тем, что на тот момент не действовали другие меры: ни жесткие экономические санкции по отношению к режиму «мясника Багдада» (Butcher of Baghdad), ни организация его физического устранения, ни смена режима иракскими диссидентами (операция ДБ/Анабейсис [Operation DB/Anabasis] стоимостью 400 млн долларов США). 
18 марта 2003 г. американцы начали операцию «Иракская свобода» (Iraqi Freedom), а спустя 3 недели «американские танки вошли в Багдад и свалили сорокафутовую статую диктатора, сторонника партии „Баас“» [Там же: 163]. 14 апреля администрация Дж. Буша-мл. объявила о победе и завершении миссии. Между тем, как полагает Д. Литтл, миссия оказалась невыполнимой (Mission Impossible) из-за ошибок, допущенных американцами на стадии нового государственного строительства, а «доктрина Буша преобразовала Ирак в нерестилище для исламских радикалов» [Там же: 167].

Неудачными можно считать и действия американской администрации в Палестине. Оказав давление на нового лидера Махмуда Аббаса, который стал палестинским президентом после смерти Ясира Арафата, в необходимости проведения демократических выборов в законодательное собрание, они после победы членов ХАМАС отказались признать их законными из-за жесткой оппозиции ХАМАС Израилю и тесной связи победителей с Ираном. По мнению Д. Литтла, «палестинско-израильские мирные переговоры, которые Буш организовал в Аннаполисе, штат Мэриленд, в конце своего второго срока, были лишней тратой времени отчасти потому, что он подсознательно уравнял ООП с Аль-Каидой» [Там же: 172]. Таким образом, ближневосточная политика администрации Дж. Буша-мл. возродила антиамериканизм от Ливии до Пакистана.

$B$ главе пять анализируются меры американской администрации по противодействию терроризму в мусульманском мире на основе доктрины Обамы «сдерживания и обязательств» (contagement), которая представляла собой сложную смесь сдерживания и обязательств по отношению к Китаю, затем Ирану и арабам» [Там же: 174].

Как пишет Д. Литтл, у нового президента США «рецепт „,держивания и обязательств“ на Ближнем Востоке казался довольно простым - Соединенные Штаты должны были принять умеренных радикалов и изолировать экстремистов» [Там же: 174]. Кроме того, необходимо было сместить акцент борьбы с государственных на негосударственные акторы, которые, по мнению Б. Обамы, представляли большую угрозу: «Полезно напомнить себе, что Усама бен Ладен не Хошимин, и что угрозы, с которыми сегодня сталкиваются Соединенные Штаты, являются реальными, многократно и потенциально разрушительными» [Там же: 177].

Другими словами, доктрина Обамы преследовала цель снизить уровень антиамериканизма на Ближнем Востоке после политики администрации Дж. Буша-мл. Что касается военного участия, то широкомасштабное участие американских войск было заменено действием спецназа и боевых дронов. В течение первых трех лет президентства Б. Обамы, таким образом, было убито «более двух тысяч боевиков, в том числе несколько граждан США и почти тысячу невинных мирных жителей» [Там же: 174].

Поэтому вряд ли можно согласиться с автором монографии о том, что американское сдерживание на Ближнем Востоке в период Б. Обамы было мирным и способствовало снижению уровня антиамериканизма. Его девиз «Давайте связывать обязательствами, но не нападать» (Let's engage, not attack) был понят арабами, как продолжение западного вмешательства другими средствами в их «другую», 
«незападную» жизнь с навязыванием чуждых им западных ценностей через поддержание целого ряда цветных революций и без того нестабильного региона.

Начало «цветным революциям» на Ближнем Востоке и в Северной Африке положила «Президентская исследовательская директива» (Presidential Study Directive 11 - PSD-11) Б. Обамы в 2010 г., которая рекомендовала СНБ заменить одиозные репрессивные режимы не тайными операциями ЦРУ, а выступлениями новой молодой национальной элиты, получившей в большинстве образование на Западе и поддерживающей западные универсальные ценности [Там же: 194].

Первой страной в череде «арабской весны» оказался Тунис, после самосожжения продавца фруктов Мохаммеда Буазизи (Mohammed Bouazizi) и поднятой социальной волны сопротивления, растиражированной средствами социальных сетей Интернета. Удавшийся эксперимент был распространен на другие страны, но с разным подходом. Так в Ливии, где оппозиция режиму была достаточно слаба, использовалась сначала военная поддержка США с организацией операции «Рассвет Одиссея» (Odyssey Dawn), а затем европейских союзников по НАТО. В Египте, где светский режим сменился на режим «братьев-мусульман», он был быстро устранен силами национальной армии.

В целом успешные, с точки зрения США, перевороты руками самих арабов во время «арабской весны» привели их к мысли о смене режима Б. Асада в Сирии. Но, как и ранее в Ираке, втягиваясь в этот процесс, американцы не имели ясного представления, кто его может заменить и не создаст ли такой переворот вакуум в региональной власти.

Д. Литтл пишет: «Когда репортер спросил госсекретаря Клинтон спустя пятнадцать месяцев, будет ли она приветствовать падение режима Асада, ее ответ был двойственен: „Зависит от того, кто его заменит“» [Там же: 202].

В этой же главе автором анализируются неудачи администрации Б. Обамы по реализации арабо-израильского мирного урегулирования. Новые строительства поселений Израилем на западном берегу р. Иордан и восточного Иерусалима только усугубили возможность мирного разрешения конфликта. Кроме того, принцип «обмена территориями и населением», взятый на вооружение израильскими политиками фактически блокировал создание палестинского государства. Отход администрации Б. Обамы от выполнения резолюции ООН от 1967 г. и трактовки eе, что по «зеленой линии» палестинцы и израильтяне должны договориться сами, означал поддержку Израиля «противодействовать созданию палестинского государства на Святой земле».

Безусловной заслугой президента Б. Обамы, по мнению Д. Литтла, является операция «Копье Нептуна» (Neptune Spear), в результате которой американским спецназом был убит Усама бен Ладен в Пакистане. В то же время он признает, что эта тайная операция, как и развернутая война боевых дронов на территориях стран Ближнего Востока, создала опасный прецедент нарушения суверенитета арабских государств без одобрения Советом Безопасности ООН и бесконтрольной гибели безвинных граждан, которых только в Пакистане погибло более 400 человек [Там же: 204]. Избирательное убийство дронами людей, которые не преследовались по американскому суду, а выбирались по списку президентом, создало другой прецедент в современной политической истории США: «Обама и Джон Брэннан, 
глава по борьбе с терроризмом, просто составили список, который иногда включал несколько американских граждан, и решали, кто должен жить, а кто должен умереть» [Там же: 206].

Шестая заключительная глава посвящена росту исламофобии в США и массовому распространению «зеленой угрозы» в течение второго срока президента Б. Обамы.

Автор считает, что непонятная президентская риторика об «обязательствах и сдерживании» никак не вписывалась в американскую политическую культуру «мы против них» и соответственно способствовала росту исламофобии в самих Соединенных Штатах.

«Существовало растущее число американцев, которые настаивали на том, что их президент был мусульманином - одним из них, а не одним из нас» [Там же: 213].

Далее, Д. Литтл на примерах из американского прошлого пытается доказать, что ксенофобия и другие расовые патологии исторически присущи американскому народу, а потому не надо удивляться, что поп-культура только стимулирует исламофобию в современных США.

В то же время он пытается обосновать историческими примерами отношение американцев к исламскому миру как «чужому», и «бремя белого человека» иметь дело с «инакомыслящими и любителями интриги» арабами [Там же: 219].

Можно согласиться с автором монографии, что в таких условиях «те американцы, которые выступили против политики „мускулов“ администрации Буша на Ближнем Востоке, „напоминали о противостоянии коммунистической партии в период холодной войны“» [Там же: 223]. Исламофобия способствовала появлению общественной организации «Остановим исламизацию Америки» (Stop Islamization of America - SIOA), влияние которой было настолько сильным, что в семи штатах законодатели внесли поправки в конституцию, запрещающие закон шариата (sharia law).

В монографии приводится реплика вновь избранного президента США Д. Трампа, сказанного им в начале президентской гонки 8 июля 2015 г. корреспонденту Си-Эн-Эн Андерсону Куперу: «С Исламским государством Ирака и Сирии надо бороться жестко и решительно. Я сделаю все, чтобы проводить политику жестко, что я даже не знаю, смогут ли они после этого сесть за стол переговоров» [Там же: 239].

Американский историк Д. Литтл предупреждает, что «в мире, рассматриваемом через призму „мы против них“ и управляемым железным законом взаимной демонизации, американская исламофобия и мусульманский антиамериканизм могут легко стать смертельно взаимными сбывающимися пророчествами» [Там же: 241]. В связи с этим автор задается вопросом: «Как можно было бы сломать этот порочный цикл взаимной демонизации?» и дает ответ: во-первых, «религиозные фанатики Америки должны сдерживать свои порывы крестоносцев и признать, что исламофобия играет только на руку мусульманским экстремистам, таким как Аль-Каида и Исламское государство Ирака и Сирии» [Там же: 244]. Во-вторых, «улучшение подорванных отношений Америки с мусульманским миром не будет ни быстрым, ни легким ... сдерживание потребует терпения, и смелое лидерство требует веры» [Там же: 245]. 
В заключение следует отметить, что более подробное знакомство с монографией Дональда Литтла будет полезно и интересно не только исследователям современных международных отношений, но и студентам, отечественным политикам, общественным деятелям, а также всем, кого волнует проблема международного терроризма.

\title{
БИБЛИОГРАФИЧЕСКИЙ СПИСОК
}

Little D. Us versus Them: The United States, Radical Islam, and the Rise of the Green Threat. Chapel Hill: University of North Carolina Press; 2016.

Дата поступления статьи: 02.03.2017

Для цитирования: Соков И.А. Рецензия на монографию: Little, D. Us versus Them: The United States, Radical Islam, and the Rise of the Green Threat // Вестник Российского университета дружбы народов. Серия: Международные отношения. 2017. Т. 17. № 2. С. $416-424$.

Сведения об авторе: Соков Илья Анатольевич - канд. ист. наук, доцент, доцент кафедры международных отношений, политологии и регионоведения Волгоградского государственного университета (e-mail: sokov@volsu.ru).

DOI: $10.22363 / 2313-0660-2017-17-2-416-424$

\section{REVIEW OF THE BOOK: \\ Little, D. Us versus Them: The United States, Radical Islam, and the Rise of the Green Threat. Chapel Hill: University of North Carolina Press, 2016. - 314 p. ISBN 978-1-4696-2680-2}

\author{
I.A. Sokov \\ Volgograd State University, Volgograd, Russia
}

\section{REFERENCES}

Little, D. (2016). Us versus Them: The United States, Radical Islam, and the Rise of the Green Threat. Chapel Hill: University of North Carolina Press.

Received: 02.03.2017

For citations: Sokov, I.A. (2017). Review of the book: Little, D. Us versus Them: The United States, Radical Islam, and the Rise of the Green Threat. Vestnik RUDN. International Relations, 17 (2), 416- 424.

\footnotetext{
About the author: Sokov Ilya Anatol'evich — PhD in History, Associate Professor of the Department of International Relations, Political Science and Area Studies of Volgograd State University (e-mail: sokov@volsu.ru).
} 